\title{
$100 \%$ endemism in mesophotic reef fish assemblages at Kure Atoll, Hawaiian Islands
}

\author{
Randall K. Kosaki ${ }^{1} \cdot$ Richard L. Pyle $^{2} \cdot$ Jason C. Leonard $^{1}$ • \\ Brian B. Hauk ${ }^{1} \cdot$ Robert K. Whitton ${ }^{2}$ • Daniel Wagner ${ }^{1}$
}

Received: 16 December 2015 / Accepted: 18 May 2016 / Published online: 26 May 2016

(C) The Author(s) 2016. This article is published with open access at Springerlink.com

The Hawaiian Archipelago is one of the most isolated island chains on Earth, and is known for a high proportion of endemism in its coral-reef fish fauna (Randall 2007). In the Northwestern Hawaiian Islands (NWHI), percent endemism based on numerical densities increases with latitude on shallow coral reefs $(<30 \mathrm{~m})$, and peaks at $62 \%$ at Pearl and Hermes Atoll (Friedlander et al. 2009). On mesophotic reefs (50$80 \mathrm{~m}$ ) of the NWHI, endemism was also found to increase with latitude, reaching a peak of $92 \%$ at Midway Atoll (Kane et al. 2014).

Here, we report the highest levels of endemism recorded from the deepest coral reefs at the northernmost atoll in the world. Surveys of mesophotic coral-reef fish assemblages were conducted using closed-circuit mixedgas rebreathers at depths of $86-91 \mathrm{~m}$ at six different sites off Kure Atoll $\left(28^{\circ} 40^{\prime} \mathrm{N}, 178^{\circ} 30^{\prime} \mathrm{W}\right)$, between September 15 and 21, 2015 (Fig. 1a). Diver transect methods were identical to those of Kane et al. (2014), and utilized a $25 \times 2 \mathrm{~m}$ visual survey at each site. These surveys represent the deepest quantitative coral-reef fish assessments ever conducted in the NWHI. Totals of 463 individuals of 17 genera and 22 species were recorded. All six surveys recorded $100 \%$ endemism, with no non-Hawaiian species noted (Fig. 1b).

Endemism is a key attribute of natural communities and is of great importance to the conservation of global biodiversity. Within the Hawaiian Archipelago, which is already considered to be a hot spot of biodiversity, the mesophotic reefs of the NWHI represent the highest endemism portion of this hot spot. Endemic species are important contributors to global biodiversity, but their restricted geographic ranges make them more vulnerable to extinction (Roberts et al. 2002). This underscores the importance of the protection afforded by large marine protected areas such as the Papahānau mokuākea Marine National Monument, which encompasses the NWHI.

Communicated by R. Thiel

Randall K. Kosaki

randall.kosaki@noaa.gov

NOAA Papahānaumokuākea Marine National Monument, 1845

Wasp Blvd., Bldg. 176, Honolulu, HI 96818, USA

2 Bernice P. Bishop Museum, 1525 Bernice St., Honolulu, HI 96817 , USA 

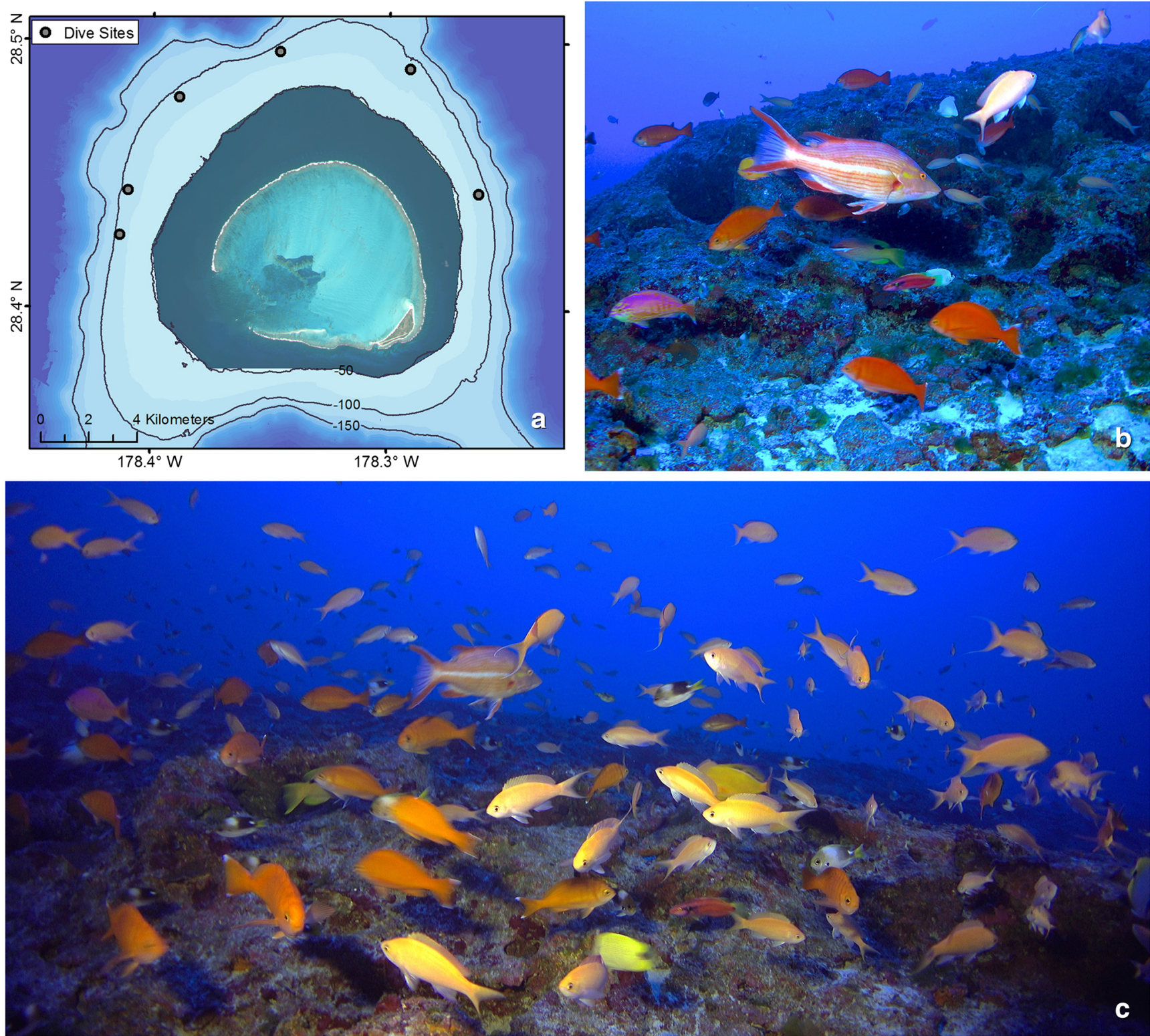

Fig. 1 a Location of mesophotic fish survey sites around Kure Atoll; b, c $100 \%$ endemic reef fish assemblage at $90 \mathrm{~m}$, including Pseudanthias thompsoni, Odontanthias fuscipinnis, Caprodon unicolor, Chromis

struhsakeri, Genicanthus personatus, Chaetodon miliaris, Bodianus albotaeniatus, B. bathycapros, and B. sanguineus
Acknowledgments We thank the NOAA ship Hi'ialakai for logistical support. L. Giuseffi, M. Winston, S. Matadobra, S. Jones, H. Owen, G. McFall, J. Copus, and R. Coleman assisted with diving and small boat operations. K. Fujii and J. Lecky assisted with figure preparation. Field work was conducted under Papahānaumokuākea Marine National Monument research permit PMNM-2015-029 issued to R. Kosaki.

Open Access This article is distributed under the terms of the Creative Commons Attribution 4.0 International License (http:// creativecommons.org/licenses/by/4.0/), which permits unrestricted use, distribution, and reproduction in any medium, provided you give appropriate credit to the original author(s) and the source, provide a link to the Creative Commons license, and indicate if changes were made.

\section{References}

Friedlander A, DeMartini E, Wedding L, Clark R (2009) Fishes. In: Friedlander A, Keller K, Wedding L, Clarke A, Monaco M (eds) A marine biogeographic assessment of the Northwestern Hawaiian Islands. NOAA, Silver Spring, pp 155-189

Kane C, Kosaki R, Wagner D (2014) High levels of mesophotic reef fish endemism in the Northwestern Hawaiian Islands. Bull Mar Sci 90: 693-703

Randall JE (2007) Reef and shore fishes of the Hawaiian Islands. Sea Grant College Program, University of Hawaii, Honolulu

Roberts CM, McClean CJ, Veron JEN et al (2002) Marine biodiversity hotspots and conservation priorities for tropical reefs. Science 295: $1280-1284$ 